\title{
Legal Studies Divested to Contract of Work PT. Freeport Indonesia
}

\author{
Tina Amelia \\ Student at Doctoral Program of Law \\ Universitas Borobudur \\ Jakarta, Indonesia \\ tinaamelia3009@gmail.com
}

\author{
Faisal Santiago \\ Faculty of Law \\ Universitas Borobudur \\ Jakarta, Indonesia \\ faisalsantiago@borobudur.ac.id
}

\begin{abstract}
Talks on divestment, especially the divestment of mining shares began to be discussed by experts and the government since the dispute over the divestment of shares between the Government of Indonesia and PT. Freeport Indonesia and PT. Newmont Nusa Tenggara. The problem of divestment in the mining sector is a problem that is getting the spotlight of many parties, because it involves a sense of nationalism of the nation. Divestment is the Government's way to carry out Article 33 paragraph (3) of the 1945 Constitution of the Republic of Indonesia (1945 Constitution of the Republic of Indonesia) that Mining on natural wealth is used for the welfare of the society. Implementation of divestment must be recognized is not easy to implement considering this concerns the continuity of a business entity and can not be denied the existence of various interests behind it. Regulation on divestment which has been arranged starting from Law Number 1 Year 1967, Law Number 25 Year 2007, Law Number 4 Year 2009, PP Number 23 Year 2010, Government Regulation Number 24 Year 2012, Government Regulation Number 77 Year 2014, Regulation of Minister of Energy and Resources Mineral Number 27 of 2013, not enough to accommodate issues related to divestment. The number of rules that exist can lead to legal dualism besides the rules have been there is not in detail set about divestment because there are things that have not been regulated in the rules. The government seemed hesitant in imposing divestment obligations to foreign investors. This certainly needs to be a record considering the existence of state control over natural resources according to the 1945 Constitution of the Republic of Indonesia. Based on the mandate of Law No. 4 of 2009 divestment, especially divestment of shares become obligations for foreign investors. However, in its development PT Freeport shares divestment experienced various obstacles during the realization. This is due to various factors such as the weakness of the applicable law, the legal uncertainty resulting from the transitional provisions of Law No. 4 of 2009, the lack of commitment from PT Freeport Indonesia and the absence of strict sanctions if the divestment obligations are not implemented. Article 119 Sub-Article a of Law Number 4 Year 2009 only regulates the revocation of permits if the holder of the license does not meet the provisions of the law while the sanction imposed only in the form of administrative sanctions. Meanwhile, other problems arise, namely the stock price offered by PT. Freeport Indonesia to the Government is too expensive which makes it difficult to realize this divestment.
\end{abstract}

Keywords - legal study, divestment, contract of work.

\section{INTRODUCTION}

Talks on divestment, especially the divestment of mining shares began to be discussed by experts and the government since the dispute over the divestment of shares between the Government of Indonesia and PT. Freeport Indonesia and PT. Newmont Nusa Tenggara. The problem of divestment in the mining sector is a problem that is getting the spotlight of many parties, because it involves a sense of nationalism of the nation. As it is known that mining is a business field open to foreign investment. In conducting such business activities, there is a divestment obligation on foreign investment as a complementary of local capital for the economic development of Indonesia in which such foreign capital will have to be released or given to the Government so that the Government may have large amount of capital or shares in a mining company.

As stated in Article 24 of the Contract of Work related to the National Interest Promotion, whereby PT. Newmont Nusa Tenggara is obligated to divest its shares firstly to the government and if the government does not accept such offer then within 30 (thirty) days from the date of the offering of such shares will be offered to Indonesian citizens or Indonesian companies controlled by Indonesian citizens . Number of shares to be divested by PT. Newmont Nusa Tenggara at the end of the 5th year of at least $15 \%$ (fifteen percent), at the end of year 6 at least $23 \%$ (twenty-three percent), at the end of year 7 at least $30 \%$ (thirty percent), at the end of the 8th year at least $37 \%$ (thirty-seven percent), at the end of the ninth year at least $44 \%$ (forty-four percent), and in the 10th year at least $51 \%$ (five twenty percent). All liabilities of the company under Article 24 paragraph (4) of the Contract of Work shall be deemed executed immediately after not less than $51 \%$ of the amount of shares issued and existing at that time have been offered to and purchased by Indonesian participants.

However, in the course of the divestment is not carried out voluntarily, causing a dispute between PT. Newmont Nusa Tenggara with the Government of Indonesia. While for PT. Freeport Indonesia itself, shares divestment discourse is felt to have many obstacles in the implementation process. This is an important note for the Government because of Law no. 4 of 2009 concerning Mineral and Coal Mining has obliged the foreign business entity holding the Mining Business License and the Special Mining Business License 
which conducts its production activities for five years to divest the shares.

\section{RESEARCH METHODS}

1. Approach Method

This research will be compiled using normative juridical research type, that is research which focused to study the application of positive law principles. Normative juridical is an approach that uses positivist legit conception. This research uses approach of legislation and case approach.

2. Research Specification

The specification used is descriptive research specification that is a research that aims to provide a concrete description or explanation of the object or problem under study without taking conclusions in general.

3. Data Source

In this study it is generally distinguished between data obtained directly from the public and library materials. Obtained directly from the community is called primary data (or baseline data), whereas those obtained from library materials are commonly called secondary data.

\section{Data Collection Method}

The results are presented in the form of descriptions arranged systematically, meaning that the secondary data obtained will be linked with each other tailored to the problems studied, so as a whole is a unified whole in accordance with the needs of research.

5. Data Analysis Method

To analyze the data obtained, will be used normative analysis method, is a way of interpreting and discussing the research material based on the definition of law, legal norms, legal theories, and doctrine related to the subject matter.

\section{PROBLEMS}

1. What is the legal arrangement of divestment of foreign mining companies in Indonesia?

2. How does the PT Freeport Indonesia divestment obligation perform?

\section{DISCUSSION}

\section{A. Legal Regulation of Divestment in Foreign Mining Companies in Indonesia}

Divestment is the transfer of assets or shares owned by the government and / or foreign investors to the other party, and the latter party is obliged to fulfill its performance in accordance with the agreed. The divestment provisions were first stipulated in Law No. 1 of 1967 concerning Foreign Investment. The birth of Law No. 1 of 1967 has the purpose of inviting foreign investors to invest in Indonesia. Article 8 of Law Number 1 of 1967 concerning Foreign Investment states explicitly that: "Foreign investment in the mining sector is based on a partnership with the government on the basis of a work contract or other form in accordance with applicable laws and regulations.

Further elaboration of the provisions contained in Article 27 of Law Number 1 of 1967 concerning Foreign Investment has been further elaborated in Government Regulation No. 20 of 1994 concerning Share Ownership in Companies Established in Foreign Capital Investment Framework. In this Government Regulation there is only one Article that regulates the divestment, especially divestment of shares owned by foreign investors. Article 7 of Government Regulation Number 20 of 1994 reads:

1) A company incorporated as referred to in Article 2 paragraph (1) letter $b$, within a maximum period of fifteen years from the commencement of commercial production sells a portion of its shares to Indonesian citizens and / or Indonesian legal entities through direct ownership or through the domestic capital market .

2) The transfer of shares as referred to in paragraph (1) and paragraph (2) does not change the status of the company.

This provision only regulates the divestment of shares against foreign capital owners. This divestiture will only be made after commercial production within a maximum period of 15 years. And the position of the company has not changed its legal status. Following the Act No. 1 of 1967 on Foreign Investment, in the mining sector also made adjustments to Law No. 1 of 1967 with the establishment of Law No. 11 of 1967 on the Basic Provisions of Mining. However, this Law does not regulate the obligation of divestment to foreign mining companies.

In 1970, Law No. 11 of 1970 on the Amendment and Supplement to Law No. 1 of 1967 on Foreign Investment was issued. However, there is no change in the provisions of Article 27 of this Law. In its development, Law No. 1 of 1967 concerning Foreign Investment as amended and supplemented by Law Number 11 of 1970 on Amendment and Supplement to Law Number 1 Year 1967 concerning Foreign Investment is no longer valid because it has been replaced by Law Number 252007 on Investment.

Two years later, in December 2009, Law No. 4 of 2009 on Mineral and Coal Mining replaced Law No. 11 of 1967 on Basic Provisions on Mining. With the issuance of this Law, a new chapter in the management of mining in Indonesia that has already accommodated the principle of regional autonomy. In addition, with the enactment of this law in the management of mining in Indonesia only recognize the permit regime and no longer recognize the contract regime as in Law No. 11 of 1967.

In relation to the current regulation on divestment referring to Law Number 4 of 2009 concerning Mineral and Coal Mining and its implementing regulation, namely Government Regulation Number 23 of 2010 concerning the Implementation of Mineral and Coal Mining Business Activities as amended by Government Regulation Number 24 Year 2012 regarding Amendment to Government Regulation Number 23 of 2010 concerning the Implementation of Mineral and Coal Mining Business Activities as amended by Government Regulation Number 77 Year 2014 on Third Amendment to Government Regulation Number 23 Year 2010 concerning the Implementation of Mineral and Coal Mining Business Activities and Minister of Energy and Mineral Resources 
Regulation number 27 of 2013 on Procedures and Determination of Share Divestment Price, as well as Changes in Capital Investment in Mineral and Coal Mining Businesses.

\section{B. Implementation of Share Divestment Obligation of PT Freeport Indonesia}

Four months after Act No. 1 of 1967 on Foreign Investment was passed, the government then signed its first mining contract with Freeport McMoran Copper \& Gold Inc. from America affiliated to PT Freeport Indonesia. The contract is known as the contract of work of generation I. This Generation I Contract of Work is an early model of the Contract of Work and is the beginning of the development of the Contract of Work.

Since 1967, the Contract of Work has been amended several times. Every change serves as the basis for the generation of contracts. Therefore, we recognize 8 (eight) generations of work contracts. The first contract of work was signed on 7 April 1967 (KK Gen. I No. 82 / EK / 4/1967) between the Indonesian government and PT Freeport Indonesia. This contract of work I is valid for 30 (thirty) years since the first production in 1973 where $100 \%$ of capital came from foreign investors in this case is Freeport McMoRan.

The contract of work I with Freeport is quite loose, since most of the material of the contract is a proposal proposed by Freeport during the negotiation process, which means more is prepared for the interests of Freeport. The contract of work I between the government and Freeport covers an area of 10,908 hectares for 30 (thirty) years, starting from the first commercial activity. The Contract of Work I contains a lot of fundamental weaknesses and is very profitable for Freeport. The main weaknesses are as follows:

1) The company used is Freeport Indonesia Incorporated, a company registered in Delaware, USA, and is subject to United States law. In other words, the company is a foreign company, and is not subject to Indonesian law.

2) In the contract there is no obligation on the environment, because at the time of the signing of the Contract of Work in 1967 in Indonesia there has been no law on the Environment. For example, as a result of the absence of environmental provisions, Freeport has since been dumping tailings into the Aikwa River, causing environmental damage.

3) Taxation arrangements are not at all in accordance with the regulations in the applicable Tax Law, either the tax type or the structure. Likewise, the depreciation rates and tariffs apply. For example Freeport is not obliged to pay the UN or VAT.

4) Freeport is granted freedom in management and operation arrangements, as well as freedom in transactions in foreign exchange. Freeport also obtained fiscal concessions, among others: tax holiday for the first 3 years after the start of production. For the next year for 7 years, Freeport is taxable only 35\%. Thereafter the tax imposed increased to about $41.75 \%$ (forty one point seventy-five percent). Freeport is also exempt from all other taxes and royalty payments on copper and gold sales except for sales tax of only $5 \%$ (five per cent).
The huge profits continue to be achieved by Freeport, until the contract of work I renewed into a second contract of Work II contract which is a work contract of the Vgeneration between the government of the Republic of Indonesia and PT Freeport Indonesia on December 30, 1991. The term of this Contract II is 2021, plus the possibility of two extensions for 10 years to 2041.

In the Freeport contract, no Article explicitly stipulates that the Indonesian government may at any time terminate the Freeport contract even if Freeport is judged to have committed violations or does not fulfill its obligations under the contract. On the other hand, Freeport may at any time terminate the contract if they judge that mining operations in its mining contract area are no longer economically profitable.

The Freeport I Contract of Work was exempted from paying taxes, royalties and dividends until 1976. While from 1976-1983 the government only imposed a corporate income tax (Pajakh) of $35 \%$ (when the prevailing tax rate was $41.75 \%)$. After 1983, the income tax imposed increased to $41.75 \%$. Throughout the years 1974-1984, renegotiation of contracts, particularly with regard to taxes and royalties, and shareholding, continued. The results of such renegotiations include the enactment of royalties of $1.4 \%-3.5 \%$ on net sales of copper, and $1 \%$ royalty on the sale of gold and silver.11 These royalty provisions are contained in the Contract of Work II.

The transfer of the contract of work of the first generation into a work contract of generation $\mathrm{V}$ requires Freeport to transfer shares to the Indonesian national party, provided that:

1) Transfer of shares up to $51 \%$ (fifty one percent) of shares to national companies / individuals within 20 years;

2) If $20 \%$ (twenty percent) of the shares are sold on the Jakarta Stock Exchange, the transfer obligation is only up to $45 \%$ (forty five percent), $25 \%$ (twenty-five percent) can be sold to national peers and individuals;

3) Five years after the signing of Freeport's contract $20 \%$ (twenty percent) of its shares must be owned by the Indonesian national party.

The terms of the divestment of shares to the government generally apply to all companies signing the work contract of Generation V. However, at that time all the companies that signed the V-generation work contract are still in the stage of general investigation or exploration, except Freeport already in production. The Freeport $\mathrm{V}$ work contract stipulates that Freeport must transfer its shares immediately after the signing of the contract of work, not later than five years after that. Freeport shares to be transferred amounted to $10 \%$ or if taken time frame 5 years, then there must be a transfer of $2 \%$ every year. Because within five years after the Freeportsigned contract of work has planned to invest heavily in Grasberg, Freeport hopes that the divestment provisions in the Generation V Contract of Work can be commercially feasible for Freeport. In 1994 the Government issued the Government Regulation No. 20 of 1994 which allowed foreign investment up to $100 \%$ and in accordance with the provisions of this Government Regulation, the divestment obligation on the Company's shares was performed after 15 (fifteen) years of production. With the issuance of this 
Government Regulation, the government's chance to own a majority stake in Freeport is lost.

In its development, since signing the Contract of Work II in 1991, Freeport has never performed its share divestment obligations. In 2004 PT Freeport Indonesia once offered its shares of $9.36 \%$ (Nine point thirty six percent), but the Minister of Finance in its letter no. S-293 / MK.02 / 2005 dated July 7, 2005 stated that the financial condition of the State does not support the Director General of Geology and Mineral Resources by letter no. 11.R / 40.00 / DJG / 2005 dated July 18, 2005 to PT Freeport Indonesia declare to offer its shares to the Government of Papua Province. Given that the Governor of Papua never filed his wish by letter no. 973/2459 / SET dated August 10, 2004 addressed to the Minister of EMR stated that the Government of Papua Province is interested in buying shares of PT. Freeport Indonesia. However, up to 2010 the offering of shares with no follow-up. This has not been resolved until the establishment of Law No. 4 of 2009.

Following the enactment of Law No. 4 of 2009 on Mineral and Coal Mining, a new phase of mining management in Indonesia was introduced in which Law No. 4 of 2009 is no longer familiar with the contract regime but only the permit regime in the form of Mining Business License. But in the transitional provisions of Law No. 4 of 2009 namely Article 169 letter a that the Contract of Work and the coal mining concession agreement that existed before the enactment of this law shall remain effective until the expiry of the contract / agreement. This means that the existing work contract before the law is enacted is still legally recognized.

However, Article 169 letter b also requires that a coal mining contract of work and agreement be finalized no later than 1 (one) year after this law is passed on the exceptions of state revenues. If we look at the provisions of this article, the statement is contradictory because on the one hand the government recognizes the existing work contract before the law is enacted, but on the other hand there is a provision to adjust the contract of work. As a provision that aims to accommodate the affected parties from changes in legislation from the old to the new legislation, this provision certainly has a vital function. However, in fact there are two contradictory interpretations of the status of the work contract when examined from Article 169 of Law Number 4 of 2009 .

The emergence of these different interpretations has proved that there are several problems in applying the divestment obligations. If connected between the provisions set forth in Article 112 and Article 169 of Law Number 4 Year 2009 this will cause a problem if the contract agreement between the government and the foreign mining company does not contain divestment. Because Article 112 has ordered the divestment of shares in companies whose shares are held by foreign investors. In order to enforce this provision, there must be a change to the contract of work. After a long process, PT Freeport Indonesia finally agreed to adjust the operation scheme from Contract of Work to Special Mining Business License and until now it has not been realized.

In connection with the divestment in 2016, Freepot finally submitted the divestment offering price of $10.64 \%$ shares worth US $\$ 1.7$ billion to the government. As quoted from CNN Indonesia Director General of Minerals and Coal (Minerba) Ministry of Energy and Mineral Resources (EMR) Bambang Gatot Ariyono admitted Freeport has submitted 100 percent valuation of its shares two days ago with a total value of US \$ 16.2 billion. So that 10.64 percent of shares that must be sold to the Indonesian side in accordance PP No. 77 of 2014 with a price of US \$ 1.7 billion.

In connection with the divestment of PT Freeport Indonesia shares, the government is still bidding on PT Freeport Indonesia's share price as it is considered too expensive. This is because most of the wealth in PT Freeport Indonesia's territory belongs to this country. According to the Director of the Center for Indonesian Resources Strategic Stusides Budi Santoso as quoted by Okezone.com that: "The divestment of shares of 10.64 percent should be valued USD500 million.Based on the count of Cirus, the value of assets of Freeport 2014 amounted to USD7, 4 billion, minus non current lialibilites USD2, 7 billion, the result is $\$ 4,7$ billion, with the stock divestment estimated at $\$ 500$ million.Cirus count refers to the government calculation, which is using the replacement cost of the asset value of Freeport minus the government assets such as roads and other school hospitals. "Thus, according to I am worth a price of only USD500 million. "The government is targeting the end of 2016, PT Freeport Indonesia divestment obligations are fulfilled The implementation of the divestment of shares should be recognized not as easy as we turn the palm of the hand considering the many obstacles in it The role and commitment of the Government becomes important in the renegotiation of the work contract to undertake the contract is more beneficial to the state in terms of state acceptance or economic empowerment in accordance with the mandate of Article 33 paragraph (2) and paragraph (3) of the 1945 Constitution considering the results of the mine is a non-renewable natural resources as a gift of God who has an important role in fulfilling the livelihood of people much so that mine management should be controlled by the State.

\section{CONCLUSIONS}

1. The implementation of divestment must be recognized is not easy to implement considering this concerns the continuity of a business entity and can not be denied the existence of various interests behind it. Regulation on divestment which has been arranged starting from Law Number 1 Year 1967, Law Number 25 Year 2007, Law Number 4 Year 2009, PP Number 23 Year 2010, Government Regulation Number 24 Year 2012, Government Regulation Number 77 Year 2014, Regulation of Minister of Energy and Resources Mineral Number 27 of 2013, not enough to accommodate issues related to divestment.

2. Based on the mandate of Law No. 4 of 2009, divestment, especially divestment of shares become obligations for foreign investors. However, in its development PT Freeport shares divestment experienced various obstacles during the realization. This is due to various factors such as the weakness of the applicable law, the legal uncertainty resulting from the transitional provisions of Law No. 4 of 2009, the lack of commitment from PT Freeport Indonesia and the absence of strict sanctions if the divestment obligations are not implemented. Article 119 Sub-Article a of Law Number 4 Year 2009 only 
regulates the revocation of permits if the holder of the license does not meet the provisions of the law while the sanction imposed only in the form of administrative sanctions.

\section{REFERENCES}

[1] W. Friedman, Teori \& Filsafat Hukum Idealisme Filosofis Problema Keadilan. (Arrengement II). Translate by Muhammad Arifin. Jakarta: Raja Grafindo, 1990.

[2] Tri Hayati, Era Baru Hukum Pertambangan di Bawah Rezim UU No. 4 Tahun 2009. Jakarta : Yayasan Pustaka Obor Indonesia, 2015.

[3] Salim HS, Hukum Pertambangan di Indonesia, Jakarta: Raja Grafindo, 2014

[4] Salim HS, Hukum Pertambangan Mineral dan Batubara, Second Print, Jakarta: Sinar Grafika, 2014.

[5] Salim HS, and Erlies Septiana Nurbani, Hukum Divestasi di Indonesia Pasca Putusan, 2013.

[6] Mahkamah Konstitusi RI Nomor 2/SKLNX/2012, Revision edition First Print Jakarta: Raja Grafindo Persada.

[7] Rcky Marbun, and friends, Kamus Hukum Lengkap Mencakup Istilah Hukum \& Perundang-Undangan Terbaru, Jakarta: Visimedia, 2012.

[8] Abdur Moin, Merger, Akuisisi \& Divestasi, Second Edition. Yogyakarta: Ekonisa, 2007

[9] Muda, dan Ahmad Toni K, Kamus Lengkap Ekonomi, Jakarta: Gita Press, 2003.
[10] Indonesia, Undang-Undang Dasar Tahun 1945

[11] Indonesia, Law Number 1 Year 1967 concerning Foreign Investment

[12] Indonesia, Law Number 11 Year 1967 regarding the provisions of the Principal Mining

[13] Indonesia, Law Number 25 Year 2007 regarding Capital Investment

[14] Indonesia, Law No. 4 of 2009 on Mineral and Coal Mining

[15] Indonesia, Government Regulation Number 77 Year 2014 on Amendment to Government Regulation Number 23 Year 2010 concerning the Implementation of Mineral and Coal Mining Business Activities.

[16] Indonesia, Government Regulation No. 24/2012 on Amendment to Government Regulation No. 23/2010 concerning the Implementation of Mineral and Coal Mining Business Activities.

[17] Government Regulation No. 23/2010 concerning the Implementation of Mineral and Coal Mining Business Activities.

[18] Indonesia, Government Regulation No. 20/1994 on the ownership of shares in the framework of foreign investment.

[19] Indonesia, Government Regulation Number 1 Year 2008 on Government Investment

[20] Indonesia, Regulation of Minister of Energy and Mineral Resources Number 27 of 2013 on Pricing and Pricing, and Capital Changes in Mineral and Coal Mining Business.

[21] Indonesia, Decision of the Constitutional Court of the Republic of Indonesia Number 2 / SKLN-X / 2012 